\title{
Mechanics of prey size preference in the gastropod Neverita didyma preying on the bivalve Ruditapes philippinarum*
}

\author{
C. L. Rodrigues** ${ }^{*}$ S. Nojima, T. Kikuchi \\ Amakusa Marine Biological Laboratory, Kyushu University, Tomioka, Reihoku-cho, Amakusa, Kumamoto-ken 863-25, Japan
}

\begin{abstract}
Laboratory experiments on Neverita didyma (Röding) preying on Ruditapes philippinarum (Adams \& Reeve) indicate distinct prey size preference which is a function of predator size. Prey size limits are determined by foot size, the organ used in capturing and handling prey. When presented with 2 prey patches equal in area but containing different prey sizes, the predator orients itself in the direction of the preferred prey size. $N$. didyma is unable to assess prey shell thickness and relies solely on prey size, gauged by the ease of 'handling', for selecting prey. Evidence and arguments are presented to show that optirnal foraging in $N$. didyma, and possibly other predators which seize their prey, evolved from passive mechanical selection leading to increased predator fitness.
\end{abstract}

\section{INTRODUCTION}

Drilling by gastropods is a relatively recent form of predation which arose during the marine mesozoic revolution wherein the infaunalization of soft-bottom benthic organisms occurred (Vermeij 1977). Noteworthy among such gastropods are the naticids and muricids which prey on bivalves. In an earlier report (Rodrigues 1986), predatory habits and functional responses of the naticid gastropod Neverita didyma preying on the bivalve Ruditapes philippinarum were described.

The present paper deals with the naticid's preference for specific prey sizes. Size selective predation is a potentially important factor affecting population structure as it may lead to the depletion of certain prey size classes (Ebling et al. 1964, Seed \& Brown 1975, Commito 1982). It has also been employed for testing optimal foraging theory, which predicts the foraging behaviour of animals by assuming that fitness is a function of foraging efficiency (Pyke et al. 1977, Hughes 1980, Pyke 1984). However, there are cases where predators did not specialize exclusively on optimally sized prey when these were abundant as

- Contribution No. 318 from the Amakusa Marine Biological Laboratory

- Present address: Department of Marine Science, Goa University, Bambolim, Goa 403 005, India expected from the optimal diet model (Hughes \& Elner 1979. Hughes \& Seed 1981, Jubb et al. 1983). Experiments were planned to investigate the prey size preference of Neverita didyma, its relation to predator size and its relevance to optimal foraging theory. Results of our experiments are compared with those obtained for other predators which seize their prey.

\section{MATERIALS AND METHODS}

The predators used, Neverita didyma, were collected in December 1984 from Tsuyazaki, Fukuoka Prefecture, in Northern Kyushu, Japan, via SCUBA diving. They were maintained in the laboratory in plastic tanks with a layer of fine sand and supplied with filtered running seawater. Additional collections were made in March 1985. The gastropods were fed an abundant supply of bivalves Ruditapes philippinarum, collected from the intertidal shore facing the Amakusa Marine Biological Laboratory (Amakusa), which served as prey. As a rule, the duration of each experiment was $7 \mathrm{~d}$, allowing a sufficient number of prey to be consumed. For standardizing hunger levels, $2 \mathrm{~d}$ starvation were found sufficient. Predators were grouped on the basis of operculum length; prey, on the basis of shell length. Size classes were arbitrarily fixed at $5 \mathrm{~mm}$ intervals. Additional details are given by Rodrigues 
(1986). Shell measurements were taken using slide calipers (accuracy of $0.1 \mathrm{~mm}$ ); whell thickness at the bore site, using dial calipers (accuracy of $0.05 \mathrm{~mm}$ ).

Shell size preference. Preference experiments were carried out in April/May 1985. The predators were individually placed in separate plastic tanks $(38 \times 26 \times$ $16 \mathrm{~cm}$, arranged in a cascade, containing a $5 \mathrm{~cm}$ layer of fine sand collected from the subtidal region. The experimental set-up consisted of 24 tanks placed in 4 rows, each row containing similar sized individuals serving as replicates. The 4 predator classes, based on the operculum length, were 20 to $25 \mathrm{~mm}, 25$ to $30 \mathrm{~mm}$, 30 to $35 \mathrm{~mm}$ and 35 to $40 \mathrm{~mm}$; the prey classes, on the basis of their shell length, were 15 to $20 \mathrm{~mm}, 20$ to $25 \mathrm{~mm}, 25$ to $30 \mathrm{~mm}$ and 30 to $35 \mathrm{~mm}$.

We conducted 3 types of prey size preference experiments. (Experiment 1) Six individuals of each prey class (total of 24) were offered to each predator in the cascade. (Experiment 2) Numbers of prey were offered that roughly presented equal surface areas to the predators; this corresponded to 6, 4, 3 and 2 individuals of the respective prey size groups. (Experiment 3 ) Nine individuals of the 15 to $20 \mathrm{~mm}$ prey class and 4 individuals of the 30 to $35 \mathrm{~mm}$ prey class (to equalize surface areas), which represented extreme size classes, were offered. In order to quantify prey size selective predation, Chesson's alpha index (Chesson 1978, 1983) was selected among the many preference indices available in the literature (see Lechowicz 1982 for recent review). This index has the advantage of being unaffected by relative abundance of food types, facilitating comparison of samples. It also allows for changing numbers of prey as they are consumed. For $m$ prey types, values above $1 / \mathrm{m}$ indicate preference. The preference index is given by the equation:

$$
\alpha_{i}=\frac{\ln \left[\left(n_{i o}-r_{i}\right) / n_{i o}\right]}{\sum_{j=1}^{m} \ln \left[\left(n_{j o}-r_{j}\right) / n_{j o}\right]} \quad i=1, \ldots m
$$

where $\mathrm{i}=$ prey type; $n_{\mathrm{io}}=$ number of prey of type $\mathrm{i}$ offered; $r_{i}=$ number of prey type i consumed.

Shell valve preference. In addition to studying size selection, the preference for either valve of the prey was studied by noting the valves drilled in the present experiments and in a previous study (Rodrigues 1986).

Shell thickness preference. We also tested whether the predators were able to assess the thickness of the prey shell or to respond to tactile clues. Prey of the same size $(25$ to $30 \mathrm{~mm}$ ) but of different handling costs were prepared by artificially grinding the shells at the umbonal region (which would in turn reduce drilling time). It was not necessary to grind other regions of the shell since the bivalves are drilled in the vicinity of the umbo (Rodrigues 1986). Post-grinding mortality was not observed. Although shell thickness decreased after grinding, the degree of reduction was not uniform among all prey and it was not possible to estimate the amount of shell material removed without sacrificing the prey. Eight each of ground and unground prey were offered to the predators in trials lasting $3 \mathrm{wk}$.

Behavioural experiments. Additional information on size selection was obtained by recording the movement of the predator, in the presence of patches of different sized prey, using an Olympus VX-304 (Japan) colour video camera. The predator (25 to $30 \mathrm{~mm}$ class) was placed in a large plastic tank $(64 \times 48 \times 14 \mathrm{~cm})$ with a $2 \mathrm{~cm}$ layer of artificial sediment (glass beads, $0.4 \mathrm{~mm}$ dia.) to provide better contrast. Four experiments were carried out. Experiment 1 served as a control and no prey were present. The movement of the predator was recorded over $24 \mathrm{~h}$ and its position at $2 \mathrm{~min}$ intervals marked. Two prey sizes ( 25 to 30 and 15 to $20 \mathrm{~mm}$ ) were then presented in patches of roughly equal areas. Movements of bivalves out of each patch were restricted by a wooden ruler. In Experiment 2, the patches were located in the proximal left and right corners of the tank. This experiment was repeated by interchanging the position of the patches (Experiment 3). In Experiment 4, the 2 prey patches were presented in the distal left and proximal right corners of the tank

Prey energy content. The prey length-weight relation, used to estimate weekly consumption of the predator, was determined by least squares regression (Sokal \& RohIf 1981). Bivalves were left in clean sea water for $24 \mathrm{~h}$ to clear their digestive tracts, and their flesh was dried in an oven at $60^{\circ} \mathrm{C}$ to constant weight. Caloric content was then determined using a microbomb calorimeter (Ogawa Seiki Co, Model O.S.K. 150, Japan) in a constant temperature room $\left(20^{\circ} \mathrm{C}\right)$. All statistical analyses are adapted from Sokal \& Rohlf (1981).

\section{RESULTS}

\section{Shell size preference}

Results of Experiments 1 to 3 are listed in Table 1. Progressively larger predators preferred larger prey both in Experiment 1 with equal number of each prey size category and in Experiment 2 with equal areas of each category. In the latter, preference indices for predator sizes 35 to $40 \mathrm{~mm}$ could not be calculated as the predators depleted all prey of sizes 30 to $35 \mathrm{~mm}$. Results of Experiments 1 and 2 were pooled to reveal the general trend of size preference exhibited by Neverita didyma (Fig. 1). The smallest predators (20 to $25 \mathrm{~mm}$ ) did not exhibit strong preferences for a particular prey group, but preference for increasingly larger prey was evident for successively larger predators 
Table 1. Neverita didyma preying on Ruditapes philippinarum. Results of preference experiments using 4 prey sizes (15 to 20,20 to 25,25 to 30,30 to $35 \mathrm{~mm}$; denoted by subscripts 1 to 4 ). The preference index used is Chesson's $\alpha$ index. and, for m prey types, values above $1 \mathrm{~m}^{-1}$ indicate preference. Values in brackets indicate number of prey offered per predator

\begin{tabular}{|c|c|c|c|c|c|}
\hline \multicolumn{6}{|l|}{ Experiment 1} \\
\hline \multicolumn{2}{|l|}{$\begin{array}{l}\text { Predator size } \\
(\mathrm{mm})\end{array}$} & $\alpha_{1}$ & $\alpha_{2}$ & $\alpha_{3}$ & $\alpha_{4}$ \\
\hline $20-25$ & & $0.284^{\circ}$ & 0.256 & 0.230 & 0.230 \\
\hline $25-30$ & & 0.217 & $0.330^{\circ}$ & $0.330^{\circ}$ & 0.122 \\
\hline $30-35$ & & 0.047 & 0.218 & $0.305^{\circ}$ & $0.430^{\circ}$ \\
\hline \multirow[t]{2}{*}{$35-40$} & & & $0.333^{\circ}$ & $0.333^{\circ}$ & $0.333^{\circ}$ \\
\hline & & (6) & (6) & (6) & (6) \\
\hline \multicolumn{6}{|l|}{ Experiment 2} \\
\hline \multirow{2}{*}{\multicolumn{2}{|c|}{$\begin{array}{l}\text { Predator size } \\
(\mathrm{mm})\end{array}$}} & \multicolumn{4}{|c|}{ Preference index } \\
\hline & & $\alpha_{1}$ & $\alpha_{2}$ & $\alpha_{3}$ & $\alpha_{4}$ \\
\hline $20-25$ & & 0.141 & $0.351^{\circ}$ & $0.321^{\circ}$ & 0.187 \\
\hline $25-30$ & & 0.106 & 0.165 & $0.348^{\circ}$ & $0.381^{\circ}$ \\
\hline $30-35$ & & 0.014 & $0.257^{\circ}$ & $0.326^{\circ}$ & $0.403^{\circ}$ \\
\hline \multirow[t]{2}{*}{$35-40 \cdots$} & & - & - & - & - \\
\hline & & $(6)$ & (4) & (3) & $(2)$ \\
\hline \multicolumn{3}{|c|}{ Experiments 1 and 2 combined } & \multicolumn{3}{|l|}{ Experiment 3} \\
\hline \multirow{2}{*}{$\begin{array}{l}\text { Predator size } \\
(\mathrm{mm})\end{array}$} & \multicolumn{2}{|c|}{ Preference index } & \multirow{2}{*}{$\begin{array}{l}\text { Predator size } \\
(\mathrm{mm})\end{array}$} & \multicolumn{2}{|c|}{ Preference index } \\
\hline & $\alpha_{1-3}$ & $\alpha_{4}$ & & $\alpha_{1}$ & $\alpha_{4}$ \\
\hline $20-25$ & $0.530^{\circ}$ & 0.470 & $20-25$ & 0.261 & $0.739^{\circ}$ \\
\hline $25-30$ & $0.574^{\bullet}$ & 0.426 & $25-30$ & 0.247 & $0.753^{\circ}$ \\
\hline $30-35$ & 0.303 & $0.697^{\bullet}$ & $30-35$ & 0.095 & $0.905^{\circ}$ \\
\hline \multirow[t]{2}{*}{$35-40$} & 0.180 & $0.820^{\circ}$ & $35-40$ & 0.145 & $0.855^{\circ}$ \\
\hline & (31) & $(8)$ & & (9) & $(4)$ \\
\hline \multicolumn{6}{|c|}{ - Values significant } \\
\hline \multicolumn{6}{|c|}{ - Indices could not be calculated as predators depleted prey size 4} \\
\hline
\end{tabular}

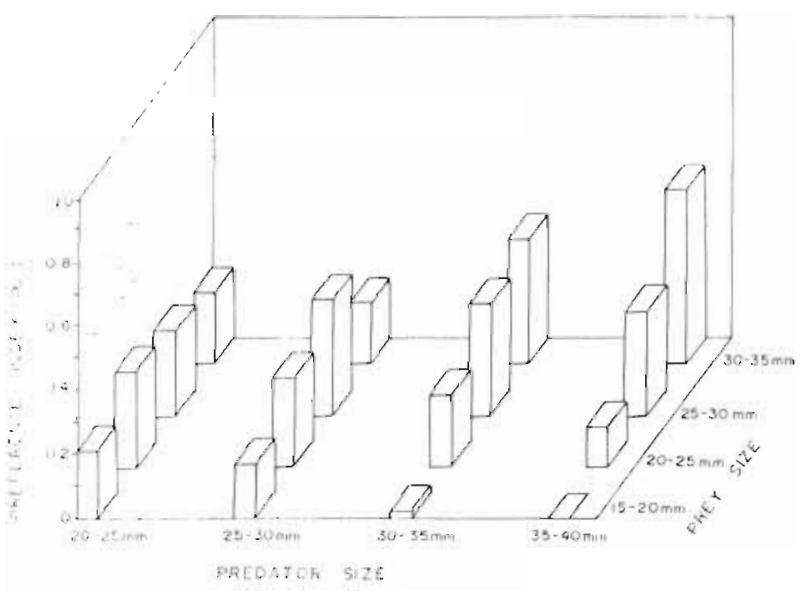

Fig. 1. Neverita didyma preying on Ruditapes philippinarum Preference of prey size as a function of predator size

(Fig. 1). When data were merged to 2 groups (15 to $30 \mathrm{~mm}$ and 30 to $35 \mathrm{~mm}$ ), recalculated preference indices showed smaller predators to prefer smaller prey, larger predators to prefer larger prey (Table 1). When extreme size groups were presented to the predators in densities roughly equalizing their surface areas, all predators attacked larger prey but smaller predators included more of small sized prey in their diet than larger predators (Table 1).

\section{Shell valve preference}

Pooling data from all experiments and analysing them via G-statistics (Sokal \& Rohlf 1981) revealed that the predators generally attacked the left valve $(\mathrm{G}=$ 30.45, df $=1, p<0.001$ ).

\section{Shell thickness preference}

When prey of the same energy content but of dissimilar handling costs, produced by artificially grinding the shell, were offered to the predators there was no sig- 
nificant difference in the consumption of the 2 types of prey $(\mathrm{G}=0.3157, \mathrm{df}=1$, not significant $)$.

\section{Behavioural experiments}

Predator positions at 2 min intervals during video experiments are illustrated in Fig. 2; for clarity, movement progression and direction are not shown. The predator mostly moved clockwise; only a few moves were anti-clockwise. Speed varied from ca $5 \mathrm{~cm} \mathrm{~min}^{-1}$
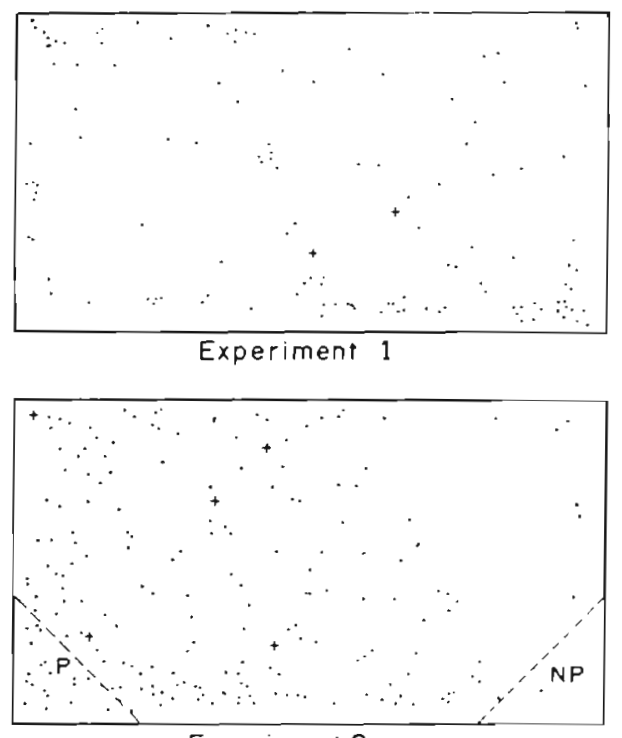

Experiment 2

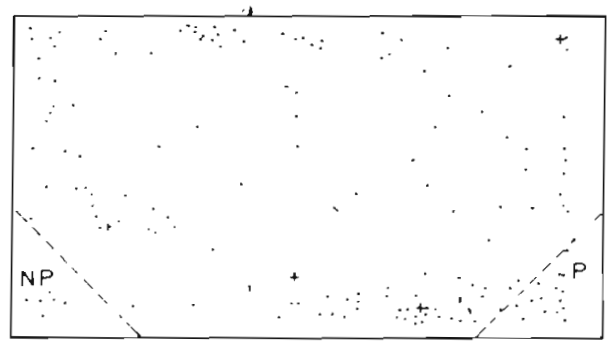

Experimen 3

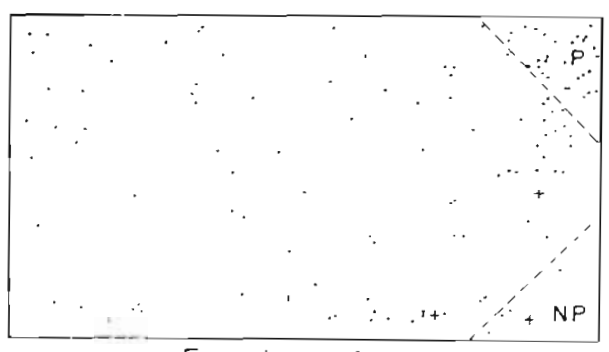

Experiment 4

Fig. 2. Position of predator Neverita didyma at 2 min intervals (dots); + : stops during video experiments using preferred prey size (P); NP: non-preferred size of prey Ruditapes philippinarum. Experiment 1 served as control. Broken line: position of barrier to restrict prey movement to $40 \mathrm{~cm} \mathrm{~min}^{-1}$ during normal activities. Higher speeds were recorded when a predator attacked a prey. Experiment 1 served as control; the predator moved around randomly (Fig. 2). However, there was a corner effect, i.e. the predator tended to move towards the edge of the tank, or into its corners. Patterns in subsequent experiments revealed that the predator tended to concentrate its movement to the region with preferred prey sizes. The predator also moved into the region of nonpreferred prey size, probably for inspection. Perhaps the trend would have been clearer had a larger tank been used.

\section{Prey value}

Prey shell length $(X)$ was significantly correlated with dry flesh weight $(Y)(r=0.98$, df $=78, p<0.001)$; the latter was estimated from the following least squares regression equation:

$$
\log \mathrm{Y}=3.32 \log \mathrm{X}-5.511
$$

Calorimetry showed $1 \mathrm{~g}$ dry flesh weight of Ruditapes philippinarum to be equivalent to $21.02 \mathrm{~kJ}$, and dry flesh weights of differently sized prey were converted into energetic values. Prey shell thickness at the bore site was significantly correlated with prey shell length $(r=0.81, d f=360, p<0.001)$; it ranged from 0.4 to $0.8 \mathrm{~mm}$ (Fig. 3). In order to determine the

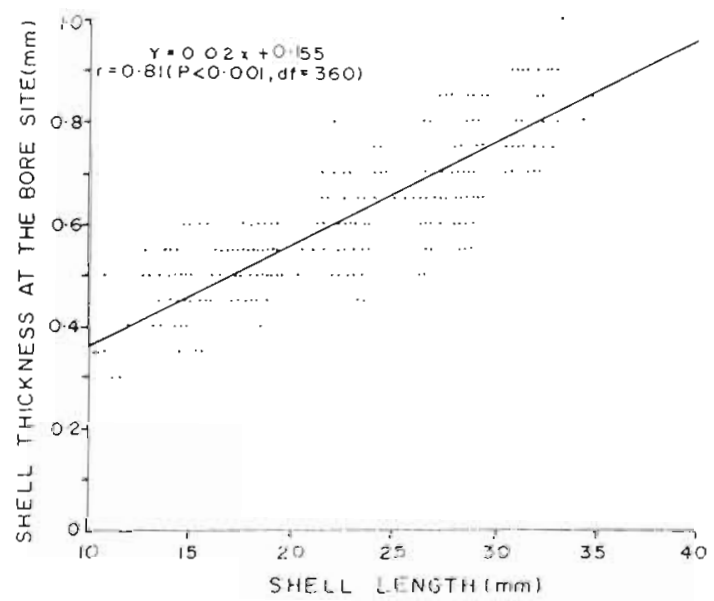

Fig. 3. Relation between shell length and shell thickness at bore site of Ruditapes philippinarum preyed by Neverita didyma

cost-benefit curve, it was assumed that the major component of handling time of the predator comprised the time spent for drilling through the prey's shell; hence the shell thickness : energetic content ratio was plotted against prey size; this revealed that larger prey are the most profitable (Fig. 4). 


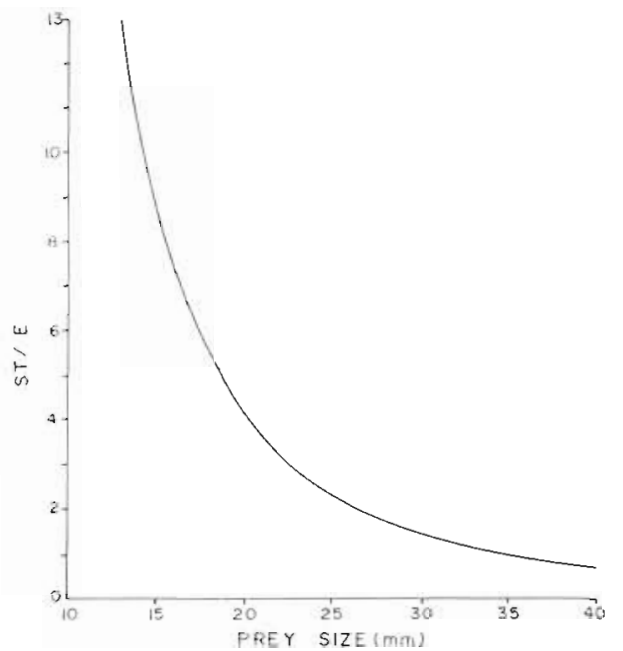

Fig. 4. Cost-benefit curve for predator Neverita didyma preying on different sizes of prey Ruditapes philippinarum. Based on shell thickness (ST):energy content (E) ratios

\section{DISCUSSION}

Prey size selection has been reported for various predators. Generally, for a particular predator size, there is an upper and a lower prey size limit beyond which prey are protected from attack and which form the 'refuge size' for prey (Paine 1976, Vince et al. 1976). Prey size limits are usually determined by the efficiency of the organs used in capturing and handling the prey (e.g. foot in the case of naticid gastropods, chela in crabs, arm in sea stars); maximum prey size imposed by such limitations generally increases with predator size. Within these limits, predators may prefer to attack a particular prey size maximizing their net rate of energy intake, in accordance with the premises of optimal foraging theory (Hughes 1980). Bayliss (1986) observed this in a naticid gastropod preying on bivalves. In the present study, prey size limits seemed to be determined by the predator's foot size (correlated with operculum size), the organ used in capturing and handling prey. This assumption is supported by size selection and video experiments. The predator is able to assess the size of the prey by moving over them during normal foraging bouts.

Does Neverita didyma use solely prey size as a criterion for selecting prey? Experiments using prey of similar energetic value but of different handling costs revealed that the predators did not select any particular prey type, suggesting that (a) $N$. didyma was unable to evaluate the artificially altered prey shell thickness and hence the handling costs involved in drilling bivalve prey, and/or (b) predators were not sufficiently 'trained' and experimental duration was too short for them to 'learn' that the altered shell sculpture signified more profitable prey. In a similar experiment, Boggs et al. (1984) concluded that naticid predators could not evaluate individual prey. Other evidence indicating that $N$. didyma is unable to assess its prey's shell thickness comes from presenting thick shelled bivalves Mactra sp. (>1 mm shell thickness) to the predator. The predator drilled incomplete bore holes before abandoning these prey (own. obs.). Although $N$. didyma was unable to assess shell thickness, it could assess prey size based on the ease of 'handling' prey with its foot.

It has proved difficult to design experiments discriminating between passive-mechanical and activebehavioural prey size selection. In Neverita-Ruditapes predation, the predator is more agile than the prey, the movements of the latter being limited except for its escape reaction (Rodrigues 1986). Although recognition time may be a factor influencing prey choice, Experiments 2 and 3 were conducted by presenting prey sizes in quantities roughly equalizing their surface areas thereby eliminating bias that causes large prey to be easily detected. The size of prey offered to the predators in the preference experiments were within the prey size limits of the predator, except possibly for the largest predator size feeding on the smallest prey size. It seems reasonable to assume that the major factor influencing handling time is prey shell thickness and that for a particular predator, the relation between drilling cost and shell thickness is linear, considering that bore dimensions are related to predator size and not prey size (Rodrigues 1986). The cost-benefit curve (Fig. 4), based on these assumptions, predicts that larger prey are always more profitable. Thus, if the predators were to select prey maximizing energy intake, they would have always preferred large prey. However, the results of the preference experiments suggest that prey size selection is a function of predator size. It was only in Experiment 3, using extreme prey size groups, that all predators preferred larger prey but, even in this experiment, smaller predators consumed 'sub-optimal' prey (Table 1). These observations suggest that prey shell thickness is not the only factor influencing handling time and that other factors such as the ease of 'handling' prey prevail in prey size selection. This explains earlier remarks that handling time depends on preference (Rodrigues 1986). The smallest predators did not exhibit any strong prey size preference as they may be clumsy at 'handling' any of the prey sizes offered or may prefer still smaller prey. Since mechanical factors must be influencing handling time, the cost-benefit curve for each predator size will differ with the most profitable prey size representing the preferred size. These curves would gradually taper on either sides as demonstrated in Carcinus maenas preying on Mytilus edulis (Elner \& Hughes 1978, 
p. 108) instead of inflecting abruptly as suggested by Kitchell et al. (1981).

The importance of mechanical factors can also be seen in other studies. Bayliss (1986) attributed the discrepancy observed in prey size selection by Polinices alderi to shell volume. In naticid-bivalve predation, prey shell thickness seems to affect only drilling time and to play no major role in either prey size or species selection. Deviations from optimal foraging theory have been observed in crab foraging behaviour, and hypotheses have been advanced to explain them (Hughes \& Elner 1979, Elner \& Raffaelli 1980, Hughes \& Seed 1981, Jubb et al. 1983). Moreover, divergent profitable prey sizes, attributable to chelal morphology, have been recorded (Elner \& Hughes 1978, Hughes \& Seed 1981). The vulnerability of gastropod shells (Vermeij 1976) and bivalve shells (Boulding 1984) to crab predation has been shown to be dependent on chela morphology and strength. The present investigation strongly suggests that prey are evaluated solely on the basis of shell size and shape which could be assessed by the ease in 'handling' the prey. Thus in crabs with chela unable to easily grasp certain sizes of prey, accidental rejection will result. In the present study, video observations did not present any evidence of prey rejection after capture, except when the predators were disturbed, as prey size was evaluated by moving over them. Optimal foraging may thus arise from mechanical consequences of chelal and prey morphology in crabs as suspected earlier (ap Rheinallt \& Hughes 1985, Lawton \& Hughes 1985, ap Rheinallt 1986) and this hypothesis may be extended to other predator-prey systems which rely on the power and dexterity of organs to seize and handle prey.

The preceeding discussion highlights the importance of mechanical factors in influencing optimal foraging theory and tends to undermine it. Ap Rheinallt (1986) remarked that although foraging appears to result entirely from mechanical factors, it does not necessarily preclude optimal foraging since the theory is not explicitly concerned with the mechanisms of prey selection. Optimal foraging theory is based on assumptions that foraging behaviour is inheritable and designed to promote fitness to the forager. A plot of the total consumption of prey tissue during each week and the change in consumption during the following week revealed a significant correlation (Fig. 5), implying that the predators foraged to obtain a constant amount of energy per week. Hence, it appears that the foraging pattern is governed by a set of rules which would perhaps optimize some characteristics, such as growth, in the predator's life cycle. Data obtained on the monthly growth of Neverita didyma throughout the study period indicated normal growth, smaller gastropods growing faster than larger ones lown unpubl.

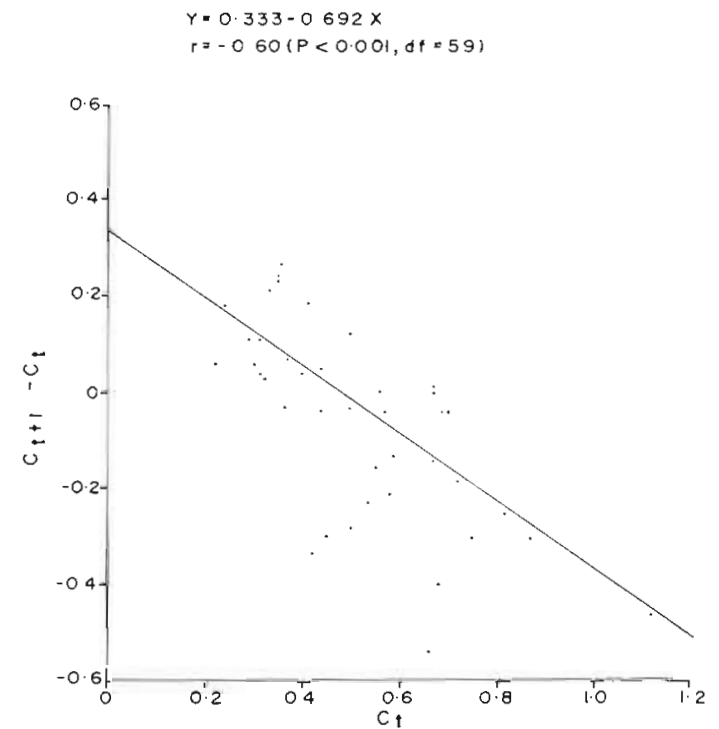

Fig. 5. Relation between consumption ( $g$ ) of prey tissue per week $\left(C_{t}\right)$ by the predator Neverita didyma and change in consumption during the following week $\left(C_{t+1}-C_{t}\right)$

data). Thus, passive mechanical factors also contribute to the fitness of the predators. The structures of the organs used in capturing and handling prey are genetically determined and along with stereotypic behaviour may have evolved to give selective advantages to the predator crucial for its survival in the community.

Acknowledgements. The authors are grateful to Dr M. Tanaka of the Amakusa Marine Biology Laboratory for his interest in the study. This work was carried out under the tenure of a Monbusho scholarship awarded to one of us (C.L.R.) by the Ministry of Education, Science and Culture, Japan.

\section{LITERATURE CITED}

ap Rheinallt, T (1986). Size selection by the crab Liocarcinus puber feeding on mussels Mytilus edulis and on shore crabs Carcinus maenas: the importance of mechanical factors. Mar Ecol. Prog. Ser 29: 45-53

ap Rheinallt, T., Hughes, R. N. (1985). Handling methods used by the velvet swimming crab Liocarcinus puber when feeding on molluscs and shore crabs. Mar. Ecol. Prog. Ser 25: $63-70$

Bayliss, D. E. (1986). Selective feeding on bivalves by Polinices alderi (Forbes) (Gastropoda). Ophelia 25: 33-47

Boggs, C. H., Rice, J. A., Kitchell, J. F. (1984). Predation at a snail's pace: what's time to a gastropod? Oecologia (Berl.) 62: $13-17$

Boulding, E. G. (1984). Crab resistant features of shells of burrowing bivalves: decreasing vulnerability by increasing handling time. J. exp. mar Biol. Ecol. 76 201-223

Chesson, J. (1978). Measuring preference in selective predation. Ecology 59: 211-215

Chesson, J. (1983). The estimation and analysis of preference and its relationship to foraging models. Ecology 64 . $1297-1304$ 
Commito, J. A. (1982). Effects of Lunatia heros predation on the population dynamics of Mya arenaria and Macoma balthica in Maine, U.S.A. Mar. Biol. 69: 187-193

Ebling, F. J., Kitching, J. A., Muntz, L., Taylor, C. M. (1.964). The ecology of Lough Ine XIII. Experimental observations of the destruction of Mytilus edulis and Nucella lapillus by crabs. J. Anim. Ecol. 33: 73-82

Elner, R. W. Hughes, R. N. (1978). Energy maximization in the diet of the shore crab, Carcinus maenas. J. Anim. Ecol. 47: 103-116

Elner, R. W., Raffaelli, D. G. (1980). Interactions between two marine snails, Littorina rudis Maton and Littorina nigrolineata Gray, a predator, Carcinus (L.) and a parasite, Microphallus similis Jagerskiold. J. exp. Mar. Biol. Ecol. 43: 151-160

Hughes, R. N. (1980). Optimal foraging theory in the marine context. Oceanogr. mar Biol. A. Rev. 18: 423-481

Hughes, R. N., Elner, R. W. (1979). Tactics of a predator, Carcinus maenas, and morphological responses of the prey, Nucella lapillus. J. Anim. Ecol. 48: 65-78

Hughes, R. N., Seed. R. (1981). Size selection of mussels by the blue crab Callinectes sapidus: energy maximizer or time minimizer? Mar Ecol. Prog. Ser. 6: 83-89

Jubb, C. A., Hughes, R. N., ap Rheinallt, T (1983). Behavioural mechanisms of size-selection by crabs, Carcinus maenas (L.) feeding on mussels, Mytilus edulis L. J. exp. mar Biol. Ecol. 66: 81-87

Kitchell, J. A., Boggs, C. H., Kitchell, J. F., Rice, J. A. (1981). Prey selection by naticid gastropods: experimental tests and application to the fossil record. Paleobiology 7 : $533-552$

Lawton, P., Hughes, R. N. (1985). Foraging behaviour of the crab Cancer pagurus feeding on the gastropods Nucella lapillus and Littorina littorea: comparisons with optimal foraging theory. Mar. Ecol. Prog. Ser. 27: 143-154
Lechowicz, M. J. (1982). The sampling characteristics of electivity indices. Oecologia (Berl.) 52: 22-30

Paine, R. T (1976). Size limited predation: an observational and experiment approach with Mytilus-Pisaster interaction. Ecology 57: 858-873

Pyke, G. H. (1984). Optimal foraging theory: a critical review. Ann. Rev. Ecol. Syst. 15: 523-575

Pyke, G. H., Pulliam, H. R., Charnov, E. L. (1977). Optimal foraging: a selective review of theory and tests. $Q$. Rev. Biol. 52: $137-154$

Rodrigues, C. L. (1986). Predation of the naticid gastropod, Neverita didyma (Röding), on the bivalve, Ruditapes philippinarum (Adams \& Reeve): evidence for a preference linked functional response. Publs Amakusa mar. biol. Lab. 8: $125-141$

Seed, R. Brown, R. A. (1975). The influence of reproductive cycle, growth and mortality on population structure in Modiolus modiolus (L.), Cerastoderma edule (L.) and Mytilus edulis L. (Mollusca: Bivalvia). In: Barnes, H. (ed.) Proceedings 9th European Marine Biology Symposium, Aberdeen Univ. Press, Aberdeen, p. $257-274$

Sokal, R. R., Rohlf, F. J. (1981). Biometry, 2nd edn. W. H. Freeman, San Francisco

Vermeij, G. J. (1976). Interoceanic differences in vulnerability of shelled prey to crab predation. Nature, Lond. 260: $135-136$

Vermeij, G. J. (1977). The mesozoic marine revolution: evidence from snails, predators and grazers. Paleobiology 3 : $245-258$

Vince, S., Valiela, 1., Backus, N., Teal, J. M. (1976). Predation by the saltmarsh killifish (Fundulus heteroclitus L.) in relation to prey size and habitat structure: consequences for prey distribution and abundance. J. exp. mar. Biol. Ecol. 23: 255-266 